\title{
Osadnictwo żydowskie
}

we wspomnieniach Pionierów

tzw. Ziem Odzyskanych.

Fragmenty pamiętników

z Kamiennej Góry i Szczecina

opracowanie:

MAREK SZAJDA

Uniwersytet Wrocławski

DOI: https://doi.org/10.26774/rzz.185

$01 / 2017$

ROCZNIK

ZIEM

ZACHODNICH

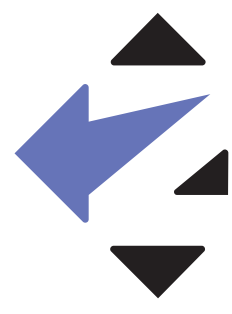


Zagadnienia tzw. repatriacji, osadnictwa i migracji na tzw. Ziemiach Odzyskanych są niewątpliwie często podejmowane przez historyków. Nie sposób wyliczyć tu wszystkich publikacji ukazujących się przede wszystkim od lat 60 . XX w. aż do chwili obecnej ${ }^{1}$. Potwierdzeniem żywotności zainteresowań w tym obszarze może być choćby wydana ostatnio praca Beaty Halickiej dotycząca kulturowego oswajania Nadodrza². W kontekście różnego typu migracji jedną z ważniejszych kwestii jest przesiedlenie ludności polskiej z terenów Związku Radzieckiego. Ważnymi celami osadniczymi dla przybyszów były Dolny Śląsk oraz Pomorze Zachodnie. Wśród migrantów sporą część grupy stanowili Żydziª . Poniższe relacje źródłowe są obrazem przebiegu akcji osadniczej ludności żydowskiej skierowanej do Kamiennej Góry w okresie późnej wiosny roku 1946 oraz osadnictwa i życia żydowskiego w podobnym okresie w Szczecinie. Omawiane źródła łączą przynajmniej dwa elementy. Pierwszym z nich jest forma oraz kontekst, w jakim powstały - zarówno zapiski Leona Dębowskiego, jak i Ireny Pawlewskiej-Szydłowskiej zostały nadesłane na konkurs na pamiętniki z tzw. Ziem Odzyskanych, przeprowadzony przez Instytut Zachodni w Poznaniu w latach 1956 i 1957. Drugi wspólny element to funkcja, jaką pełniły obie postaci w miejscowych urzędach - praca w referacie ds. osadnictwa, w przypadku Pawlewskiej-Szydłowskiej również kierowanie powołanym w drugiej połowie 1946 r. Komisariatem ds. Produktywizacji Ludności Żydowskiej w woj. szczecińskim. Autorzy pamiętników swoje kontakty z Żydami uznali, jeśli nie za ważne, to co najmniej za ciekawe, skoro zamieścili je we wspomnieniach. Niewiele przechowywanych w Instytucie Zachodnim pamiętników zawiera tego typu opisy.

Pierwszy tekst jest wyjątkiem z zapisków Leona Dębowskiego, ówczesnego pracownika Referatu Osiedleńczego przy Urzędzie Pełnomocnika Rządu na Obwód $\mathrm{nr} 28^{4}$. Autor jest osobą bliżej nieznaną. Pochodził z terenów wiejskich z okolic Łomży; w momencie pisania wspomnień miał 55 lat. Z ważniejszych informacji należy przytoczyć tę o jego zaangażowaniu w kwestię osadniczą w Kamiennej Górze już od roku 1945. Omawiany fragment relacji dotyczy tematu przesiedlenia ludności żydowskiej z ZSRR. W dość długim, biograficznym opisie swoich pionierskich wspomnień autor poświęcił kilka stron historii przybycia Żydów do Kamiennej Góry, procesowi ich osiedlania. Co warte odnotowania, w okresie od maja do lipca w miejscowym

1 Zob. m.in. klasyczne już opracowania: K. Kersten, Repatriacja ludności polskiej po II wojnie światowej: studium historyczne, Wrocław 1974; J. Czerniakiewicz, Repatriacja ludności polskiej z ZSRR. 19441948, Warszawa 1987; T. Szarota, Osadnictwo miejskie na Dolnym Ślasku w latach 1945-1948, Wrocław 1969; F. Kusiak, Osadnictwo wiejskie w środkowych i północnych powiatach Dolnego Ślaska w latach 19451949, Wrocław 1982; E. Kościk, Osadnictwo wiejskie w południowych powiatach Dolnego Ślqska w latach 1945-1949, Wrocław 1982.

2 B. Halicka, Polski Dziki Zachód. Przymusowe migracje i kulturowe oswajanie Nadodrza 1945-1948, Kraków 2015.

3 Łacznie w roku 1946 z ZSRR przybyło 136579 Żydów, za: Wysiedlenia wypędzenia i ucieczki 19391959. Atlas ziem Polski, red. G. Hryciuk, W. Sienkiewicz, Warszawa 2008, s. 143.

4 Więcej o osadnictwie w Kamiennej Górze zob.: Kamienna Góra. Monografia geograficzno-historyczna miasta i okolic, red. S. Michalkiewicz, Wrocław 1985, s. 156-162. 
komitecie zarejestrowało się 1661 osób, co czyniło tę grupę dość sporą społecznością ${ }^{5}$ Język wspomnień oraz cały ich kontekst przekazuje dużą ilość informacji o stosunku Dębowskiego do przyjezdnych oraz szerzej, o relacjach polsko-żydowskich w omawianym okresie. Jedną z ważniejszych kwestii jest także praca ludności żydowskiej na roli, budząca w autorze co najmniej mieszane uczucia.

Pewnym komentarzem do tego problemu mogą być badania Aliny Całej, która kilka dekad później, w latach 80 . XX w. przeprowadzała wywiady w społecznościach wiejskich różnych obszarów Polski odnośnie do obecności Żydów w kulturze ludowej i pamięci zbiorowej. Jak ustaliła badaczka, „wedle wielu poglądów, kontakty międzygrupowe ograniczały się do sfery gospodarczej, gdzie jedna strona była sprzedawcą, druga - klientem. Respondenci rzadko uwzględniali zróżnicowanie zawodowe wśród wyznawców judaizmu. Wyliczając zajęcia, którymi trudnili się Żydzi, 61 osób na pierwszym miejscu postawiło handel. Inne, nawet jeśli zostały wymienione, rzadko brane były pod uwagę w dalszej rozmowie" ${ }^{\prime \prime}$. Skojarzenie ludności żydowskiej z pracą na roli pojawiło się jako przedostatnie, zaledwie u ośmiorga ankietowanych. Niewątpliwie w stereotypowym postrzeganiu Żydzi mogli zajmować się jedynie handlem, którym parali się przez wieki, zwłaszcza w okresie nowożytnym, ale również powszechnie w międzywojniu. Zajęcie to było źle kojarzone, zwłaszcza przez chłopów, przede wszystkim ze względu na możliwość spekulacji. Aleksander Hertz w tym kontekście pisał, że „[...] i dla chłopa, i dla szlachcica handel był rzeczą uboczną, pochodną, wypływającą z zasadniczej działalności gospodarczej, jaką było rolnictwo. [...] Ale Żyd nie był rolnikiem. Cały szereg przysłów polskich mocno mu to wypomina. Żyd był jedynie wyłącznie kupcem"”. Takie wyobrażenia podzielano jeszcze w drugiej połowie XX w.

W rzeczywistości w powojennej strukturze zawodowej ludności żydowskiej największą grupę stanowili rzemieślnicy: ok. 27\%, kupcy zaledwie 3,4\%, rolnicy 0,6\%8. Podejmowana po roku 1945 przez Centralny Komitet Żydów w Polsce produktywizacja ludności żydowskiej, miała na celu przezwyciężenie „stanu rozpaczy i apatii [po Zagładzie - M.S.], odzyskania poczucia zdolności do działania i kontrolowania własnego życia"9, jak również umożliwienie normalnego funkcjonowania w różnych sektorach gospodarki. W wielu przypadkach tworzenie żydowskich spółdzielni rolniczych zapewniało względne poczucie jedności i bezpieczeństwa społeczności. Dla nie-Żydów takie działania były niezrozumiałe ${ }^{10}$. Być może odczytywano je w kategoriach

B. Szaynok, Ludność żydowska na Dolnym Ślasku 1945-1950, Wrocław 2000, s. 50.

$6 \quad$ A. Cała, Wizerunek Żyda w polskiej kulturze ludowej, Warszawa 2005, s. 21.

$7 \quad$ A. Hertz, Żydzi w kulturze polskiej, Warszawa 2003, s. 261.

8 M. Grynberg, Żydowska spółdzielczość pracy w Polsce w latach 1945-1949, Warszawa 1986, s. 23.

9 P. Kendziorek, Program i praktyka produktywizacji Żydów polskich w działalności CKŻP, Warszawa 2016, s. 151

10 Zob. P. Dziurżyński, Osadnictwo rolne na Ziemiach Odzyskanych, Warszawa 1983. Praca ta, szczegółowo opisująca zagadnienie, nie porusza kwestii osadnictwa żydowskiego na roli, zaangażowania Żydów w gospodarkę rolną w okresie powojennym. 
potencjalnego zagrożenia utraty gospodarstw na rzecz Żydów. Andrzej Rykała, który w sposób szczegółowy badał to zagadnienie, stwierdził, iż „wielu osobom podjęcie działalności rolniczej utrudniał opór natury psychologicznej, wynikający m.in. z obawy o reakcję ludności nieżydowskiej"11.

Dolny Śląsk w pierwszych latach po wojnie był obszarem dynamicznego osadnictwa żydowskiego. W miastach na południu województwa, przede wszystkim w Dzierżoniowie, Bielawie, Pieszycach, Wałbrzychu, ale również w sąsiadujących z nimi Kamiennej Górze, Jeleniej Górze czy Kłodzku, zamieszkiwały dziesiątki tysięcy Żydów ${ }^{12}$. Większość z nich stanowili żydowscy migranci z ZSRR, przybyli w pierwszym półroczu roku 1946. Bożena Szaynok opisując funkcjonowanie tej społeczności na podstawie raportów Komitetów Żydowskich, szczegółowo zanalizowała różne problemy zarówno migrantów, jak i z migrantami ${ }^{13}$. Spośród kilku problemów ważnych w kontekście relacji warto wymienić przynajmniej dwa. Pierwszym jest niewątpliwie niechęć do przyjmowania żydowskich transportów. Oczywiście sytuacja w każdym z miast była inna, podobnie jak stopień zasiedlenia, liczba wciąż pozostających Niemców czy stan mieszkań. Niewątpliwie, co potwierdzają dokumenty, liczne były wypadki nieprzychylnego odnoszenia się do przybywających, podobnie działo się w kwestii zatrudniania Żydów. Kolejnym problemem była mobilność ludności - opuszczanie miejscowości, do których skierowano transporty, porzucanie przeznaczonych do osadnictwa mieszkań. Patrząc przez pryzmat takich kategorii jak bezpieczeństwo, potrzeba przebywania w dużym skupisku żydowskim, kwestia Żydów pozostawiających wsie na rzecz dolnośląskich miasteczek wydaje się jeszcze bardziej skomplikowana i nie taka oczywista.

Druga relacja stanowi wyjątkowe źródło chociażby ze względu na postać autorki wspomnień - Ireny Pawlewskiej-Szydłowskiej, działaczki społecznej, pionierki taternictwa oraz byłej więźniarki obozów koncentracyjnych. Równie istotna jest perspektywa, z jakiej pisała tekst - praca w roli Wojewódzkiego Komisarza ds. Produktywizacji Ludności Żydowskiej ${ }^{14}$.

Irena Pawlewska-Szydłowska (7 lutego 1892 - 18 lutego 1982, primo voto Fabrycy) urodziła się we Lwowie jako córka Henryki z Michałowskich Pawlewskej - ciotecznej siostry Marii Skłodowskiej-Curie, działaczki na rzecz równouprawnienia kobiet, oraz Bronisława Pawlewskiego - profesora nauk chemicznych, rektora Politechniki

11 A. Rykała, „Produktywizacja” Żydów w Polsce po drugiej wojnie światowej na przykładzie działalności rolniczej, „Prace i Studia Geograficzne”, t. 61 (2016), z. 1, s. 159.

12 Dolny Śląsk stanowił wówczas tzw. osiedle żydowskie, zamieszkałe przez ok. 100 tys. Żydów, zob. A. Ilwicka, Grand Illusion? The Phenomenon of Jewish Life in Poland after the Holocaust in Lower Silesia „The Person and the Challenges”, t. 4 (2/2014), s. 102-104.

13 B. Szaynok, op. cit., s. 44-49.

14 Komisariat Rządu dla Spraw Produktywizacji Ludności Żydowskiej w Polsce - instytucja działająca na rzecz produktywizacji Żydów w różnych sektorach gospodarki, powołana przez Rade Ministrów, funkcjonująca w okresie od 25 VII 1946 do 11 IX 1947 r. zarówno na stopniu centralnym, jak i wybranych województwach. 
Lwowskiej w latach 1895-1896 oraz 1909-191015. To za sprawą zainteresowań ojca Szydłowska jeszcze jako dziecko zainteresowała się turystyką górską, zwłaszcza eksploracją Tatr. Zanim jednak została pionierką w tej dziedzinie, odebrała gruntowne wykształcenie, m.in. kończąc studia z zakresu nauk matematycznych i przyrodniczych na paryskiej Sorbonie oraz lwowskim uniwersytecie. Do największych osiągnieć Szydłowskiej niewątpliwie należą samotne lub tylko w towarzystwie kobiecym wejścia na tatrzańskie szczyty. W 1908 r. wraz z Heleną Dłuską dokonała pionierskiego wejścia na Szczyrbski Szczyt nową drogą z Hlińskiej Doliny ${ }^{16}$. Irena Pawlewska była niezwykle aktywną osobą. Prócz zaangażowania w Towarzystwie Tatrzańskim, działała również w Lidze Ochrony Przyrody. W okresie I wojny światowej zaciągnęła się do kobiecego oddziału Związku Strzeleckiego we Lwowie. Podczas kolejnego globalnego konfliktu działała w okupowanej Warszawie w ramach ZWZ. Aresztowana przez Gestapo w roku 1941, trafiła najpierw na Pawiak, a dalej do obozów w Ravensbrück i Neubrandenburg. Po wojnie w roku 1946 przyjechała do Szczecina, gdzie spędziła kolejne lata ${ }^{17}$. Tu też znalazła pracę w Urzędzie Wojewódzkim. Zajmowała się tam m.in. sprawami osadniczymi oraz produktywizacją Żydów. Tego okresu dotyczą zamieszczone poniżej wspomnienia. W roku 1974 Szydłowska przeniosła się do Poznania, gdzie zamieszkała w Domu Weterana. Tam też zmarła osiem lat później.

Inteligenckie pochodzenie autorki, znajomość różnych środowisk, zaangażowanie społeczne, jak również doświadczenia obozowe stanowią ważny kontekst jej sposobu myślenia i opisywania społeczności żydowskiej w Szczecinie. Omawiane wspomnienia nie są bowiem stereotypowym zapisem, lecz w miarę obiektywnym, zewnętrznym spojrzeniem na tę mniejszość. Autorka nie stroni w nich od poruszania ważnych zagadnień związanych z życiem Żydów. Wspomina o partiach politycznych na ulicy żydowskiej, problemach dotyczących migracji, opisuje nastroje antysemickie oraz udział Żydów w strukturach aparatu bezpieczeństwa. Jako osoba odpowiedzialna za produktywizację sporą część prezentowanego fragmentu wspomnień poświęca Szydłowska kwestii zatrudnienia Żydów w różnego typu instytucjach. Jej uwaga skupia się m.in. na zatrudnieniu w sektorze rolnictwa, do którego odnosi się optymistycznie, $w$ przeciwieństwie do Leona Dębowskiego. Sprawa ta była niezwykle ważna dla Żydów działających w komitetach, o czym świadczą artykuły zamieszczane w lokalnym „Tygodniku Informacyjnym. Organie Wojewódzkiego Komitetu Żydów Polskich w Szczecinie”. W drugim numerze tego pisma donoszono: „Jak już podaliśmy [...], osiedlono dotychczas około 500 Żydów w majątkach państwowych w powiatach starogardzkim i choszcznowskim. [...] Ludzie chętnie wyjeżdżają

15 Hasło: Pawlewski Bronisław, [w:] Polski słownik biograficzny, red. E. Rostworowski, t. XXV, Wrocław 1979 , s. $419-421$.

16 Hasło: Pawlewska-Szydłowska Irena, [w:] Wielka encyklopedia tatrzańska, red. Z. Radwańska-Paryska, W. Paryski, Poronin 2004, s. 890

17 Zob.: Drzewka Pamięci na Cmentarzu Centralnym w Szczecinie. Pawlewska-Szydłowska Irena, http:// www.cmentarze.szczecin.pl/chapter_50362.asp?soid=1164A6AE564946B0B7859A7AC444B8AA (dostęp: 5 XII 2016 r.). 
na rolę. Pracą swoją i energią wykazują, że mit o niezdolności Żydów do pracy rolnej jest fikcją"18. Tym samym pomorscy, a także dolnośląscy rolnicy żydowscy urastali do miana symbolu procesu produktywizacji. Stanowili również przykład równouprawnienia oraz nowego życia żydowskiego w powojennej Polsce.

Szczecin i całe Pomorze Zachodnie były w pierwszych latach po wojnie ważnym miejscem na mapie osadnictwa żydowskiego w Polsce. Na skutek akcji przesiedleńczej z ZSRR w połowie 1946 r. województwo szczecińskie było zamieszkane przez niespełna 31 tys. osób, głównie w stołecznym mieście ${ }^{19}$. Wraz z emigracją pokielecką liczba ta malała, by w kolejnym roku po tragicznych wydarzeniach osiągnąć nieco ponad 6 tys., co w skali całego kraju stanowiło ok. 7\% ludności żydowskiej w Polsce ${ }^{20}$. Działalność i funkcjonowanie społeczności do 1950 r. było tematem kilku artykułów i książek. O Żydach na tym terenie pisali przed laty m.in. I. Białostocki ${ }^{21}$ czy Janusz Mieczkowski ${ }^{22}$; temat ten poruszano również w wielu pracach zbiorowych $^{23}$. Relacja Szydłowskiej nie jest więc kolejnym tekstem o samej społeczności, raczej przyczynkiem traktującym o postrzeganiu jej przez pryzmat osoby, która zawodowo zajmowała się wspieraniem zatrudnienia Żydów w poszczególnych sektorach gospodarki, również udzielaniem wsparcia finansowego dla poszukujących pracy lub do niej niezdolnych ${ }^{24}$. Jest to zatem relacja urzędniczki, która, nie będąc członkiem tej grupy, była z nią mocno związana na skutek codziennych kontaktów.

Stosunek obojga autorów do kwestii osadnictwa żydowskiego w wielu miejscach jest odmienny. Jest to widoczne nie tylko w prowadzonej narracji, opisach poszczególnych sytuacji, ale również w języku oraz osobistych uwagach zawartych w pamiętnikach. Na tego typu postawy wpływ miało z pewnością zarówno doświadczenie wojny, pochodzenie społeczne, sprawowana funkcja, jak i wcześniejsze kontakty

19 J. Mieczkowski, Żydzi, Niemcy i Ukraińcy na Pomorzu Zachodnim w latach 1945-1956. Liczba, położenie i działalność polityczna, Szczecin 1994, s. 17

20 Wysiedlenia, wypędzenia..., s. 145-146.

21 I. Białostocki, Wojewódzki Komitet Żydów Polskich w Szczecinie (1946-1950), „Biuletyn ŻIH”, nr 71-72 (3-4/1969), s. 83-105.

22 J. Mieczkowski, Żydzi, Niemcy...; idem, Między emigracjq a asymilacjq: szkice o szczecińskich Żydach w latach 1945-1997, Szczecin 1998; Żydzi szczecińscy tradycja i współczesność. Materiały z sesji naukowej 27 czerwca 2003 r., red. K. Kozłowski, J. Mieczkowski, Szczecin 2004. W pierwszej pracy autor przytacza fragment wspomnień I. Pawleskiej-Szydłowskiej; posługuje się nim przy opisie społeczności żydowskiej. Podobnie zob.: Z. Dulczewski, Socjologiczne aspekty migracji ludności na pomorzu zachodnim, [w:] Przeobrażenia społeczne na Pomorzu Zachodnim w latach 1945-1947, red. Z. Dulczewski, Poznań 1964, s. 108.

23 Zob.: Pomorze Zachodnie w latach 1945-2010. Społeczeństwo-władza-gospodarka-kultura, t. I, red. K. Kozłowski, Szczecin 2012, s. 74-80; S. Jankowiak, Przemiany narodowościowe na "Ziemiach Odzyskanych” po II wojnie światowej, [w:] „Ziemie Odzyskane” po drugiej wojnie światowej, red. C. Osękowski, G. Strauchold, Zielona Góra 2015, s. 33-43.

24 Ostatnio fragment wspomnień Szydłowskiej opublikowała Beata Halicka w wyborze fragmentów pamietników z Instytutu Zachodniego. Znalazła się tam również część prezentowanego opisu dot. ludności żydowskiej, zob.: B. Halicka, Mój dom nad Odrq. Pamiętniki osadników Ziem Zachodnich po 1945 roku, Kraków 2016 
z Żydami. Dębowski w swojej relacji często opisuje Żydów w sposób stereotypowy, ukazując tę grupę jako obcych, niemile widzianych na nowych terenach, ludzi żyjących niejako obok, niepasujących według niego do nowej rzeczywistości Ziem Zachodnich. Ludność żydowska przedstawiona jest negatywnie, m.in. poprzez posługiwanie się językiem rosyjskim czy posiadaniem skrzyni o domniemanej bogatej zawartości. Relacjonowana rozmowa na stacji kolejowej ukazuje niezrozumienie różnych doświadczeń i problemów społecznych Polaków oraz Żydów. Inaczej jest w przypadku Szydłowskiej, która ówczesne położenie ludności żydowskiej ulokowała w kontekście zarówno Zagłady, jak i przedwojennej sytuacji społecznej. Ponieważ jej kontakty z tą grupą objęły dłuższy okres, to też wpłynęło na różnorodny oraz wieloaspektowy opis szczecińskiej społeczności (zagadnienia polityki, produktywizacji, kultury). W końcu wspomnienia te zostały spisane z perspektywy kolejnych lat i wydarzeń: emigracji części społeczności z Polski, upadku żydowskich osiedli, a także odwilży 1956 r., w czasie której ożywiły się nastroje antysemickie.

Na końcu warto wspomnieć również o pochodzeniu źródła, zaczerpniętego z zasobu Instytutu Zachodniego w Poznaniu. Niniejsze wspomnienia zostały wysłane na pierwszy konkurs na pamiętniki Pionierów tzw. Ziem Odzyskanych, który odbył się w latach 1956-195725. Omawiane fragmenty są zaledwie niewielką częścią nadesłanych rękopisów, traktujących o pierwszych, powojennych latach. Na konkurs przysłano 227 prac, które ostatecznie trafiły do zbioru pamiętników (74 teksty dotyczyły ówczesnego woj. wrocławskiego), niektóre z nich opublikowano. Jak deklarowali organizatorzy konkursu: „Celem tej akcji było uzyskanie materiału naukowego, ilustrującego proces i rozwój osadnictwa oraz związanie z nim przeżycia i postawy osadników"26. Wśród wielu tematów poruszanych na kartach pamiętników dominowały te związane z osadnictwem, relacjami z ludnością niemiecką, pionierskim wysiłkiem i „budowaniem polskości” na nowych terenach ${ }^{27}$. W wielu relacjach pojawiały się również problemy, związane z konfliktami społecznymi, politycznymi, aprowizacją itp. Niewiele uwagi autorzy prac poświęcali „obcym”, którymi dla wielu niewątpliwie byli wówczas Żydzi ${ }^{28}$. Choćby z tego względu poniższe relacje są warte uwagi.

Prezentowane fragmenty są dobrym przykładem szeroko rozumianej literatury wspomnieniowej, którą wielu badaczy uznaje za niezwykle specyficzne źródło.

25 Konkurs został ogłoszony w grudniu 1956 r. Kolejne dwa konkursy tego typu odbyły się w roku 1966 oraz 1970

26 Cyt. za: Pamiętniki osadników Ziem Odzyskanych, oprac. Z. Dulczewski, A. Kwilecki, Poznań 1963, s. 15.

27 Więcej o kontekście pamiętników i ich opracowań w wyborze nadesłanych wspomnień opracowanym przez pracowników naukowych Instytutu Zachodniego w Poznaniu, zob. ibidem, s. 5-27; Z. Dulczewski, Społeczne aspekty migracji na Ziemiach Zachodnich, Poznań 1964, s. 62-93. W szerszym kontekście o kwestii pamiętników pisała również H. Tumolska, zob. H. Tumolska, Mitologia Kresów Zachodnich w pamiętnikarstwie i beletrystyce polskiej (1945-2000). (Szkice do dziejów kultury pogranicza), Torun 2008, s. 88-93.

28 Również w pracach naukowych często pomijano kwestię ludności żydowskiej. Przykładem tego jest praca S. Kaczkowskiego, który opisuje migrantów przybyłych do Szczecina z ZSRR tylko w kategoriach ludności polskiej. Zob. S. Kaczkowski, Stosunki ludnościowe Szczecina w latach 1945-1955, Warszawa 1968, s. 110-119. 
Zapisywane bowiem na kartach pamiętników minione dzieje często uzupełniane są przez autorów późniejszymi wydarzeniami czy przemyśleniami; czasami zaś ich prezentacja ma charakter schematyczny. Na jakość wspomnień wpływają m.in. trauma, bieżąca sytuacja (w tym także społeczno-polityczna), dystans czasowy, strategie narracyjne autora oraz wiele innych czynników. Dość często można określić tego typu źródła jako wartościowe poznawczo, lecz niedokładne w szczegółach.

Tekst wspomnień został poprawiony gramatycznie i językowo w miejscach, gdzie było to koniecznie dla zrozumienia całości wypowiedzi. W pozostałej części zachowano oryginalną pisownię, składnię oraz podział na ustępy.

\section{Fragment wspomnień Leona Dębowskiego, 1956 r.}

Źródło: Archiwum Ziem Zachodnich i Północnych Instytutu Zachodniego im. Zygmunta Wojciechowskiego w Poznaniu (AIZwP), Konkurs na pamiętnik osadnika Ziem Odzyskanych z grudnia 1956 r., sygn. P201, s. 4-8 (mps).

Miało to miejsce w lecie 1946 roku. Kiedy pewnego dnia po powrocie $\mathrm{z}$ terenu zjawiłem się w biurze, okazano mi otrzymany przed chwilą z Wydziału Osiedleńczego Urzędu Wojewódzkiego we Wrocławiu telefonogram powiadamiający nas, że skierowany do nas został transport żydów ${ }^{29}$ polskich i że transport ten miałem przyjąć i osiedlić.

Przyznam się, że mnie wtedy zatkało. W miastach powiatu żadnych wolnych miejsc nie było i pozostawała tylko wieś, ale czy dla żydów? Czyż żyd umie i czy zechce stanąć za pługiem i wziąć do ręki kosę? Nie, tu jest coś nie w porządku. Zamówiłem niezwłocznie telefon do Wrocławia, a w międzyczasie połączyłem się z PUR-em ${ }^{30}$. Okazało się, że PUR otrzymał również od swoich władz zwierzchnich identyczny jak i ja w sprawie tego transportu telefonogram i właśnie sam się teraz "głowił" nad wyszukaniem wyjścia z tej kłopotliwej sytuacji. Po naradzie postanowiliśmy, że o ile po rozmowie jaką mam odbyć z Wrocławiem, transport będziemy zmuszeni przyjąć bezwzględnie, przyjmiemy go, damy przybyłym gorącej kawy i chleba z marmeladą, bo na gotowanie czegoś treściwszego nie ma już czasu, a po tym skierujemy go w teren i żydów osiedlimy na gospodarstwach rolnych. Odezwał się w końcu Wrocław. W rozmowie, jaką odbyłem z jednym z dygnitarzy Wydziału osiedleńczego próbowałem skłonić województwo do skierowania będącego już w drodze transportu gdzieindziej, powoływałem się na składane już od dłuższego czasu przez siebie meldunki o wyczerpaniu chłonności w miastach powiatu. Tłumaczyłem, że osiedlanie żydów na roli jest pozbawione wszelkiego sensu, nic to jednak nie pomogło. Odpowiedź na moje perswazje i zaklęcia była jedna: osiedlić tam, gdzie się da i koniec.

29 Autor konsekwentnie używa słowa „Żyd” w odniesieniu do grupy narodowościowej, pisząc je małą literą.

30 PUR, właściwie Państwowy Urząd Repatriacyjny - instytucja mająca za zadanie koordynację i organizację tzw. repatriacji ludności polskiej do Polski w okresie tuż powojennym. Zob. D. Sula, Działalność przesiedleńczo-repatriacyjna Państwowego Urzędu Repatriacyjnego w latach 1944-1951, Lublin 2002. 
Wściekły na wojewódzkiego dygnitarza, który przeprowadza akcję osiedleńczą za biurkiem i na arkuszu papieru, a który teren zna tylko ze sprawozdań, a repatriantów z opisów w prasie, odłożyłem słuchawkę i posławszy mu wiązankę wyszukanych polskich „życzeń” z których „nagła krew” i „jasna cholera” były „życzeniami” najskromniejszymi, zabrałem się do wydania zarządzeń osiedleńczych w sprawie tego nieszczęsnego transportu. Zamówiłem więc telefonicznie gminy, w których postanowiłem transport osiedlić, a kiedy pierwsza z nich odezwała się wziąłem za słuchawkę i zacząłem nadawać telefonogram tej treści: „Do Urzędu Gminy w ... Kieruje się do was wagon repatriantów żydów. Wymienionych należy przyjąć i przenocować a w dniu jutrzejszym osiedlić na gospodarstwach rolnych". Początkowo referentka gminna, która przyjmowała nadawany przeze mnie telefonogram zachowywała się spokojnie, ale kiedy rzuciłem jej do słuchawki, że żydzi mają być osiedleni na roli, przerwała mi jakby niedowierzając: „przepraszam, przepraszam... gdzie? Żydzi na gospodarki?...”, a kiedy przytaknąłem wrzasnęła na cały swój urząd: „Panie wójcie, panie wójcie... proszę do telefonu tylko prędko!... Żydów nam przysyłają!... Na gospodarki!..." Za słuchawkę ujął w gminie wójt. Powtórzyłem mu raz jeszcze telefonogram, a wtedy znowu się zaczęło: „Czyś pan oszalał?” - darł się jakby go kto zarzynał. „Żydów mi pan przysyła? Na gospodarstwo. A oni mi na jaką cholerę?... Nie przyjmę... Nie osiedlę... Ja żydowi gospodarstwa nie dam!"

Wytłumaczyłem wściekającemu się wójtowi, że go rozumiem i że próbowałem tego transportu nie przyjąć, ale że wydział osiedleńczy nakazuje nam kategorycznie żydów przyjąć i osiedlić i na zakończenie pocieszyłem go tym, że według mnie żydzi sami odmówią objęcia gospodarstw, a co z tego wynika, że skończy się wszystko tylko na zamieszaniu. To widocznie poskutkowało, bo wójt się trochę udobruchał i zrezygnowany oświadczył mi na zakończenie naszej rozmowy: „Trudno, niech ich pan przysyła".

Dalsze nadawanie tego nieszczęsnego telefonogramu zleciłem już personelowi swego biura, sam zaś wyszedłem i udałem się w kierunku dworca, bo zapowiedziany transport powinien był wkrótce nadejść. Po drodze i z rozpaczy, „że najgorsze z tym transportem pewnie się dopiero zacznie", wypiłem szklankę modnej wówczas „Tata z mamą" ${ }^{31}$.

Na dworcu kolejowym oczekiwał mnie już przedstawiciel PUR-u i kilku milicjantów, a wkrótce nadszedł również i transport. Kiedy pociąg z repatriantami przestawiono na boczną linię, podeszliśmy z przedstawicielem PUR-u do wagonów i zapytaliśmy o kierownika transportu. Zjawił się wkrótce jakiś starszy już Żyd i przywitawszy się z nami oświadczył: „Ja jestem komendant tego transporta”32, po czym i jakby dla podkreślenia ważności swojej osoby dodał: „jestem członek zaziondu polskie patrioty z gorod Samara". Po takim ceremonialnym przedstawieniu się komendant transportu zapytał nas, co zamierzamy teraz z transportem uczynić, w związku

31 „Tata z mamą” - rodzaj napoju alkoholowego uzyskiwanego z połączenia wysokoprocentowej wódki lub spirytusu z sokiem owocowym. 
z czym odpowiedziałem mu tak: „Najpierw wyznaczy pan po dwóch ludzi z każdego wagonu po gorącą kawę i po dwóch również z każdego wagonu po chleb z marmeladą, kiedy się posilicie, transport odejdzie $\mathrm{w}$ teren, gdzie was osiedlimy na gospodarstwach rolnych".

Kiedy komendant transportu i przysłuchujący się naszej rozmowie żydzi dowiedzieli się, że zamierzamy osiedlić ich na roli, w pociągu zakotłowało się jak w piekle; wśród trudnego do opisania wrzasku żydzi poczęli wyrzucać z wagonów toboły i wyskakiwać i gdyby nie natychmiastowa interwencja milicji, w pociągu nie byłoby wkrótce nawet żywej duszy.

Podczas kiedy milicja była zajęta ładowaniem żydów z powrotem do wagonów, komendant transportu wdał się $\mathrm{z}$ nami ponownie w rozmowę i próbował wytargować zmianę decyzji osiedlenia żydów na roli. „Ja pana powim jednego - mówił. Po co wy dajecie żydki na gospodarki? My tam nic nie umiemy, nam cieba dać do sklepika, do warsztata, albo do fabryka, a nie na gospodarki!... To cieba zmienić!"

Wytłumaczyłem komendantowi, że owszem dalibyśmy im chętnie tego upragnionego „warsztata i sklepika” ale że wszystko jest już zajęte, wobec czego damy im to, czym rozporządzamy tj. gospodarstwa rolne. Rozmowę zakończyłem $w$ ten sposób: „Każdy z was otrzyma gospodarstwo rolne, a czy je przyjmiecie czy też nie, to jest już tylko wasza sprawa”. Na takie „dictum” komendant grzmotnął się tylko pięścią po udzie i oświadczywszy nam, że on na wsi nie pozostanie „za ziadna cholera". Zrezygnowany powlókł się do wagonu. Słyszałem jeszcze jak gramoląc się już do wagonu rzucił prawdopodobnie pod moim adresem: „Cholera, on mnie cienstuje z chlebem i kawem!... Chodź pętaka do wagona, ja ci pokazie ziarcie!" I rzeczywiście żydzi byli tak obficie zaopatrzeni i to w dodatku w różne niedostępne dla nas smakołyki, iż trudno było im się dziwić, że wzgardzili naszą polską kawą z jęczmienia, marmeladą z buraków i nadpsutych jabłek i wypiekanym według „recepty” niezrozumiałej nawet dla piekarzy chlebem. Każdy z nich posiadał bowiem i prawdziwą herbatę i kawę, całe skrzynie przeróżnych konserw i skondensowanego mleka oraz duże ilości amerykańskich papierosów.

Ostatecznie transport po częściowym tylko pobraniu kawy został rozbity i najbliższym pociągiem odszedł w teren, ja zaś powlokłem się do hotelu i rzuciwszy się na łóżko w ubraniu, przeleżałem tak do rana. Jak było do przewidzenia, żydzi odmówili objęcia zaproponowanych im gospodarstw i w przeciągu kilku najbliższych dni opuścili teren powiatu udając się w większości do pobliskiego Wałbrzycha. Tam istniały jeszcze możliwości otrzymania i „sklepika” i warsztata” i można było jeszcze handlować bez przeszkód i „z waziwem” i „z owocem” a nawet „i z cukierkiem”.

\section{Fragment wspomnień Ireny Pawelskiej-Szydłowskiej, 1956 r.}

Źródło: AIZwP, Konkurs na pamiętnik osadnika Ziem Odzyskanych z grudnia 1956 r., sygn. P210, s. 22-27 (mps).

Któregoś dnia, wiosną [19]46 r. wpada do mnie naczelnik Wydziału osiedleńczego: „Mamy zasygnalizowane z Ministerstwa transporty Żydów z ZSRR. Będą w tych dniach. Nie wiem jeszcze czy przyjadą do Stargardu czy tutaj. Dużo już skierowano 
na Śląsk. - Jak my ich tu zatrudnimy? Rozmawiałam już z Zarembą (1-szy prezydent Szczecina). - Jeśliby zostali tu skierowani, wyznaczono dla nich dwie dzielnice: Golęcin i Niebiszewo. - Proszę być w stałym kontakcie z PUR-em".

Zdziwiłam się, dlaczego [przeznaczyli na to - M.S.] oddzielnie dzielnice, jakieś ghetto... W parę dni po tym Szczecin zaroił się od Żydów. Na ulicach, bazarach, w nielicznych sklepach, na przystankach tramwajowych, wszędzie ich było pełno. Rozmawiali krzykliwie, głośno, przeważnie po rosyjsku lub żargonem ${ }^{34}$, z właściwą sobie żywą gestykulacją. W tym czasie w Szczecinie było niecałe jeszcze 50 tys. mieszkańców; Żydów w przeciągu kilku tygodni przybyło ponad 30 tys. Było dla mnie dziwne i niezrozumiałe, że Żydom nie daje się wracać do ich rodzinnych miejsc zamieszkania, lecz pcha się ich na samą granicę niemiecką. Wątpiłam czy mogą się tu czuć pewnie i bezpiecznie wobec niezbyt przecież ustabilizowanej pozycji naszej na tych ziemiach.

Do biura naszego rozpoczęła się istna procesja Żydów pojedynczych i grupkami. Przychodzili syjoniści ${ }^{35}$, pepeerowcy, bundowcy ${ }^{36}$, członkowie świeżo powstałego Komitetu Żydów Polskich i przedstawiciele najrozmaitszych grup i drobnych grupek, wszelkich tak licznych u nich odcieni politycznych. Przeważnie wychudzeni, wyniszczeni ciężką pracą fizyczną, wystraszeni. Kto by tam poznał w niejednym dzisiejszym dumnym dyrektorze, wypasionym adwokacie czy groźnym tajemniczym Szefie UB biednego, nieśmiałego repatrianta z [19]46 roku.

Wielu Żydów dopiero w Szczecinie dowiedziało się o męczeństwie i śmierci swoich rodzin, inni oczekiwali i szukali prawie zawsze tragicznych wiadomości. Z ich domów, warsztatów pracy i przedsiębiorstw też pozostała tylko garść popiołu. Samotni organizowali się $\mathrm{w}$ kibuce ${ }^{37}$, w których żyli zwarci jak w rodzinie, odcięci od otaczającego społeczeństwa. Wejścia do kibucu pilnował strażnik z karabinem. Dla młodzieży zorganizowano internat. Część najuboższych Żydów Zarząd Miejski zatrudnił przy zamiataniu ulic. Nie mogłam patrzeć na te kolumny obszarpanych, bladych biedaków, prowadzonych środkiem ulicy, tak jak prowadzili ich podczas okupacji Niemcy, podczas gdy cywilni robotnicy niemieccy zatrudnieni u Rosjan, porządnie odziani, z butnymi minami i głośno rozmawiając po niemiecku jeździli

33 Piotr Zaremba (1910-1993) - architekt i urbanista, profesor Politechniki Szczecińskiej, prezydent Szczecina w latach 1945-1950.

34 W języku jidysz, określanym też jako żydowski.

35 Syjonizm - ruch polityczno-społeczny domagający się utworzenia siedziby narodowej Żydów w Palestynie z językiem hebrajskiem jako językiem narodowym. Na jego podstawie powstały liczne partie polityczne, m.in. o charakterze marksistowskim czy socjalistycznym, np. Poalej-Syjon.

36 Bund, właściwie Ogólnożydowski Związek Robotniczy „Bund” - żydowska partia polityczna o pogladach socjalistycznych, opowiadająca się za tworzeniem silnego społeczeństwa żydowskiego w diasporze (w tym przypadku w Polsce), dysponującego swoistą autonomią kulturalną; przeciwna działalności stronnictw syjonistycznych. Była jedną z największych partii żydowskich w okresie międzywojennym.

37 Kibuc - określenie odnoszące się do grupy, wspólnoty żyjącej w sposób kolektywny, pierwotnie wspólnie uprawiających rolę, dzielących między siebie wszelkie przychody itp. Kibuce tworzyły m.in. organizacje o charakterze syjonistycznym. 
do pracy samochodami. Na szczęście i nasze władze, i Joint Amerykański ${ }^{38}$ przyszli szybko z pomocą w gotówce, artykułach żywnościowych i odzieży. Najtrudniejszy problem teraz to było zatrudnienie tych ludzi.

Tymczasem w Szczecinie zaczęły to tu, to tam wybuchać antysemickie nastroje. Na targu doszło do jakiejś bójki między sprzedającymi, jeden z Żydów został ciężko pobity, inny został napadnięty gdzieś na torach za miastem. Znajomi moi na noc zabarykadowali drzwi wejściowe stołami i szafkami. Chorzy Żydzi w szpitalu dostawali dużo dobrych zagranicznych lekarstw i drogich paczek żywnościowych. Polscy pacjenci byli bardzo słabo zaopatrzeni. Zazdrość budziła najniższe instynkty. Nieraz słyszałam osoby skądinąd uczciwe i wartościowe, które ze złością mówiły, że trzeba będzie wyjeżdżać ze Szczecina, gdyż jest on widocznie przeznaczony specjalnie na żydowską siedzibę. Jak się później dowiedziałam, znaleźli się nawet wśród pracowników obsługujących repatriantów, ludzie, którzy już na granicy polskiej potrafili Żydom powiedzieć, że nie wiadomo po co wracają do Polski, są tu wcale niepotrzebni. Szkoły hitlerowskiej i haniebnej tradycji bojówek ONR ${ }^{39}$ nie wytrzebiło z umysłów niektórych, nielicznych na szczęście, Polaków nawet to morze potwornych prześladowań i zagłady narodu żydowskiego.

W województwie i Zarządzie Miejskim naradzano się usilnie jak ich rozmieścić, jak zatrudnić. Uważałam, że łączenie Żydów w jakieś specjalne grupy, mimo pewnych momentów przemawiających za tym, jest co najmniej niewłaściwe w naszym ustroju, rzuca jakieś specyficzne oświetlenie na stosunek nas do nich, przeczy zasadzie internacjonalizmu. Uważałam, że gdyby Żydzi zostali rozmieszczeni w niewielkich ilościach po wszystkich miasteczkach województwa, gdzie praca ich mogłaby być bardzo przydatna, obecność ich nikogo by nie raziła. Również wobec braku rąk do pracy na wsi i wobec tego, że wielu z nich pracowało na roli w ZSRR, planowaliśmy skierowanie niektórych rodzin do PGR-ów ${ }^{40}$. Być może, że nie doceniliśmy wtedy jak silny jest pęd Żydów do tworzenia i szerzenia własnej narodowej kultury, do zrzeszania się we własnych odrębnych zrzeszeniach polityczno-społecznych; nie rozumieliśmy, że dla bardzo wielu z nich przyjazd do Polski jest tylko etapem przybliżającym ich do wyjazdu, już na stałe do Izraela.

W [19]46 r. zjawił się w Urzędzie Wojewódzkim Komisarz Rządu dla Spraw Produktywizacji Ludności Żydowskiej, który przyjechał zapoznać się z jej warunkami w Szczecinie i zorganizować wojewódzki odpowiednik swojej centralnej placówki. Ówczesny przewodniczący Komitetu Żydowskiego, będąc ze mną w bliskim kontakcie i przyjaznych stosunkach zaproponował mnie na stanowisko Wojewódzkiego

38 Właśc. American Jewish Joint Distribution Committee - organizacja działająca w Stanach Zjednoczonych, wspierająca finansowo życie żydowskie w powojennej Polsce.

39 ONR, właść. Obóz Narodowo-Radykalny - prawicowa organizacja polityczna funkcjonująca w latach 30. XX w. W swojej działalności jawnie propagowała wrogość oraz przemoc wobec ludności żydowskiej, por. B. Michlic, Obcy jako zagrożenie. Obraz Żyda w Polsce od roku 1880 do czasów obecnych, Warszawa 2015, s. 161

40 PGR, właść. Państwowe Gospodarstwo Rolne - rodzaj gospodarki rolnej o charakterze socjalistycznym, regulowanej przez państwo, funkcjonującej w Polsce w latach 1949-1993. 
Komisarza dla tych spraw. Nie przerywając swej pracy w akcji osadnictwa miejskiego z wielkim zapałem zabrałam się do swego nowego zadania.

Niebawem zaczęłam kierować pierwsze rodziny żydowskie do PGR-ów. Warunki życia i pracy były tam jeszcze wtedy niezmiernie ciężkie i nie można było na miejscu nic kupić, do miasta nie było czym dojechać, żadnej pomocy lekarskiej i weterynaryjnej. Bezpieczeństwo też wątpliwe. Po swej ciężkiej tułaczce po ZSRR Żydzi rolnicy wpadli na Ziemie Odzyskane jak z przysłowiowego „deszczu pod rynnę”. Praca tych pierwszych rolników Żydów była naprawdę pracą pionierską; z tych właśnie rodzin powstały później znane w województwie spółdzielnie produkcyjne Kanie i Ustowo, które w chwili, gdy to piszę, mężnie stawiają czoło iście owczemu, tak bardzo szkodliwemu, pędowi do rozwiązywania spółdzielni bez względu na to czy dobrze, czy też źle gospodarują.

Współpracowałam usilnie również w organizowaniu spółdzielni „Rybak Szczeciński", która miała swą siedzibę w Trzebieży nad Zalewem. Wielu ludzi, nawet i Żydów, nie wierzyło, że z Żydów mogą być dobrzy rybacy. „Rybak Szczeciński” dowiódł, że tak nie jest. Z prymitywnym sprzętem rybackim, z niewielką liczbą fachowców, spółdzielnia miała jednak często bardzo dobre połowy. Ogólna zła organizacja skupu ryb i niedostateczna opieka nad rybołówstwem, które doprowadziły do ruiny wiele spółdzielni i rybaków indywidualnych, doprowadziły i „Rybaka” do upadku. Niestety też wśród jego członków znaleźli się ludzie, którzy zaczęli się trudnić przemytnictwem i przeprowadzaniem ludzi przez granicę. Sprawa skończyła się „na Kaszubskiej” (więzienie szczecińskie). W Szczecinie powstało wiele dobrze prosperujących spółdzielni rzemieślniczych, inni Żydzi pracowali w przedsiębiorstwach państwowych. Obok tego jednak rozwijał się intensywnie „czarny rynek”. Przed Komitetem cały dzień roiło się od Żydów handlujących czym się dało, ponoć złotem i dewizami. Bardzo niepokoił mnie fakt, że tak dużo Żydów, także kobiet, zgłasza się do pracy w Urzędzie Bezpieczeństwa. Przestrzegałam przed tym tych, z którymi żyłam bliżej, niestety bezskutecznie. Fale antysemityzmu, które wezbrały w Polsce po XX Zjeździe [w 1956 r. - M.S.], pokazały jak bardzo miałam rację w tym wypadku. Okres mojej pracy w akcji osiedleńczej i jako komisarza był bardzo bujnym okresem mojej działalności. Ściągnął jednak na moją głowę bardzo duże, niespodziewane i niezmiernie krzywdzące mnie przykrości, o których powiem dalej.

Jeszcze powracam do Żydów. Spragnieni po pobycie w ZSRR swobodnego, szerokiego życia polityczno-społecznego organizowali masę zebrań, wieców, akademii, imprez artystycznych. Na wiecach niezmiernie ożywionych, dochodziło często do bardzo ostrej wymiany zdań, a nawet i do rękoczynów. Moje jednak przemówienia były zawsze gorąco oklaskiwane. Myślę, że wynikało to stąd, że byłam głęboko przekonana o tym, co mówiłam. A mówiłam, że Żydzi muszą się czuć pełnoprawnymi obywatelami PRL, że my marksiści polscy chcemy żyć i pracować z nimi na zasadach pełnego internacjonalizmu, chcemy wytępić resztki przesądów rasistowskich. Wskazywałam jak piękne zadanie mają Żydzi na Ziemiach Odzyskanych, budując tu, na terenach, zagarniętych przed laty przez Niemców, Słowiańszczyźnie, życie polskie, oparte na nowym ustroju. Wtedy klaskali mi pepeerowcy i bundowcy. Zaraz jednak dodawałam, że Rząd Polski i polska demokracja uznają w pełni prawo narodu żydowskiego 
do własnej ojczyzny, do własnego państwa i tym Żydom, którzy pragną budować Izrael, żadnych przeszkód stawiać nie będzie. W tym miejscu syjoniści z tryumfem spoglądali na marksistów i starali się prześcignąć ich w oklaskach.

Niezapomniane wrażenie robiły na mnie niektóre wieczory ku czci obrońców Ghetta, a już specjalnie żałobne pieśni kantora i inscenizacje oparte na tematach z okupacji wspaniałej żydowskiej artystki dramatycznej Idy Kamińskiej. Poznałam z bliska społeczeństwo żydowskie i ogromnie się z nim zżyłam. Do dziś mam sporo przyjaciół wśród Żydów szczecińskich.

\section{Bibliografia}

Białostocki I., Wojewódzki Komitet Żydów Polskich w Szczecinie (1946-1950), „Biuletyn ŻIH”, nr 71-72 (3-4/1969), s. 83-105

Cała A., Wizerunek Żyda w polskiej kulturze ludowej, Warszawa 2005

Czerniakiewicz J., Repatriacja ludności polskiej z ZSRR. 1944-1948, Warszawa 1987

Dulczewski Z., Socjologiczne aspekty migracji ludności na pomorzu zachodnim, [w:] Przeobrażenia społeczne na Pomorzu Zachodnim w latach 1945-1947, red. Z. Dulczewski, Poznań 1964

Dulczewski Z., Społeczne aspekty migracji na Ziemiach Zachodnich, Poznań 1964

Dziurżyński P., Osadnictwo rolne na Ziemiach Odzyskanych, Warszawa 1983

Grynberg M., Żydowska spółdzielczość pracy w Polsce w latach 1945-1949, Warszawa 1986

Halicka B., Mój dom nad Odrq. Pamiętniki osadników Ziem Zachodnich po 1945 roku, Kraków 2016

Halicka B., Polski Dziki Zachód. Przymusowe migracje i kulturowe oswajanie Nadodrza 1945-1948, Kraków 2015

Hertz A., Żydzi w kulturze polskiej, Warszawa 2003

Ilwicka A., Grand Illusion? The Phenomenon of Jewish Life in Poland after the Holocaust in Lower Silesia, „The Person and the Challenges”, t. 4 (2/2014), s. 97-126

Jankowiak S., Przemiany narodowościowe na „Ziemiach Odzyskanych” po II wojnie światowej, [w:] „Ziemie Odzyskane” po drugiej wojnie światowej, red. C. Osękowski, G. Strauchold, Zielona Góra 2015 Kaczkowski S., Stosunki ludnościowe Szczecina w latach 1945-1955, Warszawa 1968

Kamienna Góra. Monografia geograficzno-historyczna miasta i okolic, red. S. Michalkiewicz, Wrocław 1985 
Kendziorek P., Program i praktyka produktywizacji Żydów polskich w działalności CKŻP, Warszawa 2016

Kersten K., Repatriacja ludności polskiej po II wojnie światowej: studium historyczne, Wrocław 1974

Kościk E., Osadnictwo wiejskie w południowych powiatach Dolnego Ślqska w latach 1945-1949, Wrocław 1982

Kusiak F., Osadnictwo wiejskie w środkowych i północnych powiatach Dolnego Śląska w latach 19451949, Wrocław 1982

Michlic B., Obcy jako zagrożenie. Obraz Żyda w Polsce od roku 1880 do czasów obecnych, Warszawa 2015

Mieczkowski J., Między emigracjq a asymilacjq: szkice o szczecińskich Żydach w latach 1945-1997, Szczecin 1998

Mieczkowski J., Żydzi, Niemcy i Ukraińcy na Pomorzu Zachodnim w latach 1945-1956. Liczba, położenie i działalność polityczna, Szczecin 1994

Pamiętniki osadników Ziem Odzyskanych, oprac. Z. Dulczewski, A. Kwilecki, Poznań 1963

Pawlewska-Szydłowska I., Drzewka Pamięci na Cmentarzu Centralnym w Szczecinie, http://www.cmentarze.szczecin.pl/chapter_50362.asp?soid=1164A6AE564946B0B7859A7AC444B8AA

Polski słownik biograficzny, red. E. Rostworowski, t. XXV, Wrocław 1979

Pomorze Zachodnie w latach 1945-2010. Społeczeństwo - władza - gospodarka - kultura, t. I, red. K. Kozłowski, Szczecin 2012

Rykała A., „Produktywizacja” Żydów w Polsce po drugiej wojnie światowej na przykładzie działalności rolniczej, „Prace i Studia Geograficzne”, t. 61 (2016), z. 1, s. 151-163

Sula D., Działalność przesiedleńczo-repatriacyjna Państwowego Urzędu Repatriacyjnego w latach 1944-1951, Lublin 2002

Szarota T., Osadnictwo miejskie na Dolnym Ślqsku w latach 1945-1948, Wrocław 1969

Szaynok B., Ludność żydowska na Dolnym Śląsku 1945-1950, Wrocław 2000

Tumolska H., Mitologia Kresów Zachodnich w pamiętnikarstwie i beletrystyce polskiej (1945-2000). (Szkice do dziejów kultury pogranicza), Toruń 2008

Wielka encyklopedia tatrzańska, red. W. Paryski, Z. Radwańska-Paryska, Poronin 2004

Wysiedlenia wypędzenia i ucieczki 1939-1959. Atlas ziem Polski, red. G. Hryciuk, W. Sienkiewicz, Warszawa 2008

Żydzi szczecińscy tradycja i współczesność. Materiały z sesji naukowej 27 czerwca 2003 r., red. K. Kozłowski, J. Mieczkowski, Szczecin 2004 
Marek Szajda

\section{Osadnictwo żydowskie we wspomnieniach Pionierów tzw. Ziem Odzyskanych. Fragmenty pamiętników \\ z Kamiennej Góry i Szczecina}

Streszczenie: Tekst prezentuje dwie relacje źródłowe przesłane na konkurs na pamiętnik osadnika Ziem Odzyskanych w latach 1956-1957, zorganizowany przez Instytut Zachodni w Poznaniu. Są to wspomnienia urzędników z Kamiennej Góry (Dolny Śląsk) oraz Szczecina, którzy w pierwszych miesiącach po zakończeniu wojny zajmowali się osadnictwem w tych miastach oraz najbliżej okolicy. Zamieszczone relacje opisują przyjazd na Ziemie Zachodnie ludności żydowskiej z ZSRR oraz proces osadnictwa. Autorzy opisują w nich zarówno warunki życia Żydów, jak i swój osobisty stosunek do migrantów oraz decyzji o zasiedleniu przez nich przeznaczonych im wsi i miejscowości, zwłaszcza znajdujących się tam gospodarstw rolnych.

\section{Jewish settlement in the recollections of the "Pioneers" to the so-called Recovered Territories. Excerpts from diaries from Kamienna Góra and Szczecin}

Abstract: This text presents two source narratives entered in the competition for the diary of a settler in the Recovered Territories in the years 1956-1957 organised by the Western Institute in Poznan. These are the recollections of local government workers from Kamienna Góra (Lower Silesia) and Szczecin who in the first months after the end of the war were concerned with the settlement of these cities and their immediate vicinities. These narratives present fragments describing the arrival of Jewish people from the USSR to the Western Territories and the process of settlement. The authors describe both the living conditions of the Jews and their own personal relationships to the migrants as well as the decision to settle these people in certain villages and towns, especially in the farms located there.

Słowa kluczowe: ludność żydowska, „Ziemie Odzyskane”, osadnictwo, Kamienna Góra, Szczecin, pamiętniki, pionierzy, produktywizacja, rolnictwo

Key words: Jewish people, Recovered Territories, settlement, Kamienna Góra, Szczecin, diaries, pioneers, productiveness, agriculture 